\title{
POLITICAL STRUGGLE IN RUSSIA IN THE SUMMER OF 1645 AND OATH OF ALLEGIANCE REGISTRIES
}

The paper is devoted to the political struggle in the upper social circles of Russia in the summer of 1645 following the death of Czar Mikhail and the coronation of his son - Alexei Mikhailovich. The author shows the contradictions that arose during the period in aristocratic circles, which are reflected in the oath of allegiance registries (krestoprivodniye (kissing of the cross or being led to the cross) zapisi) used when the population of towns swore their allegiance to the new czar in July-August 1645. The author concludes that the summer 1645 political struggle in Russia did not take on a wide scope because the opponents of boyar B. I. Morozov, who had come to power, hoped to achieve a quick victory or at least a compromise. All this is reflected in the registries, made when the oath of allegiance to the new czar was given. However, several years later, on realizing that no success had been achieved, the opposition began to use more wide-ranging methods of struggle that led to the uprising of the populace in 1648 .

Keywords: oath of allegiance registries; oath; czar Alexei Mikhailovich; B.I. Morozov.

In spite of the fact that Czar Mikhail Fedorovich had been ill for some time, his death came as a surprise to Russian society, especially in the provinces where information about the czar's health took a while to reach them. In the last years of Mikhail's reign Russia entered a difficult economic time. Various groups within the population exerted pressure on the government, demanding privileges, reformation of the tax system and unification of land legislation. Social tensions escalated, especially in connection with the struggle between the landlords and the so-called "strong people", the great landowners [Смирнов, с. 50-60]. It was under these conditions that Alexei Mikhailovich became czar, the first czar of a new dynasty, who inherited the throne by right of birth. Moreover, for many years, rumors were spread in the country that Prince Alexei was not Mikhail's son and that the legitimate heir was in hiding [Бахрушин, с. 87-118].

In the previous papers I argued how political strife developed between 1647-1650 in the provinces and in the upper court circles [Ляпин, 2010, с. 15-28]. This paper demonstrates how the conflicts among the ruling elite began to form in 1645. Although not obvious at the time, the subsequent upheavals that happened in Russia occurred as a direct result of the 1645 events. 
Even before Mikhail Fedorovich died, the aristocracy struggled for power, primarily because the heir to the throne was very young. For most of the ruling elite it was clear that power would pass into the hands of Alexei's teacher and close friend, boyar Boris Ivanovich Morozov. Quite a number of influential people were dissatisfied with Morozov's power (Ya. K. Cherkassky, I. N. Romanov, N. I. Romanov, the Sheremetevs, and others). For this reason they worded their own version of the oath of allegiance registry, in which the name of Czarina Eudoxia Lukyanovna was put first [Андреeв, c. 60]. They hoped that a system of regency would be installed, which included guardianship, making it possible to ease B. I. Morozov from power. But a second version of the oath of allegiance registry was drafted and pronounced the official one; in it the name of the czarina was placed after Alexei's name, a fact which made the czar an autocratic ruler.

However, Eudoxia Lukyanovna's name was placed also in the second version of the oath of allegiance registry. This can be explained by the fact that the czarina was very popular with the people, demonstrated in her biography. First, she was chosen in 1626 by Czar Mikhail Fedorovich from many other young girls for her beauty and "gentle disposition". Secondly, the czarina became the founder of a number of religious institutions. She assisted the poor and the church, and with her help, St. George's Monastery in Meschovsk (Kaluga region) was restored [Щербакова]. Finally, by 1645 it was important to show that the country was ruled by a legitimate royal dynasty, not by a group of influential boyars, the great landowners. This is why the name of the czarina was placed next to the name of the new czar. Yet in reality, it is highly improbable that Eudoxia Lukyanovna played any great role in the political life of the court or the country, in part because she died a sudden death on August 18, 1645.

As a result of the political strife among the upper circles after Mikhail's death, undisclosed persons were appointed to go to Russian towns. Their task was to make the local population swear allegiance ("to lead them to the cross"). Importantly, local town voevodas were not allowed to do it by themselves. The voevoda was considered a military commander, and for that reason was seen as a military unit of an uezd town (chief town of a district). There are exceptions, however; in Mtsensk, for example, the rules of swearing the oath of allegiance were broken, and the local voevoda, V. Sheremetev, led the people to the cross to swear allegiance on his own. Stolnik (rank below that of boyar) I. Lykov, who had come to Mtsensk especially with this aim, expressed his disapproval, but the awkward situation was settled quickly. Why was it that V. Sheremetev was in such a hurry to show his independence without waiting for an envoy from the capital to come? Most probably, the relative of an influential boyar, Fedor Ivanovich Sheremetev, encouraged V. Sheremetev's actions to show his independence and his desire to fight the power seized by aristocrats, in opposition to B. I. Morozov.

The means by which the people took the oath of allegiance to Czar Alexei Mikhailovich in the summer of 1645 is reflected in the oath of allegiance registries. In spite of the fact that this type of document contains valuable 
and interesting information [Кошелева, с. 155-157], it has been seldom cited in recent research. The oath of allegiance registries were drafted in all towns of Russia between July-August 1645. The main aim of these registries was to make the whole population of the towns and the uezds (districts) swear allegiance (to be performed by kissing the cross) to the new czar.

The population of Moscow was the first to swear allegiance to Alexei Mikhailovich. The boyar, A.N. Trubetskoy, was sent to the regiments in Tula who at that time were waiting for an attack from the Crimean Tatars, one of many typical for the time [Андреев, с. 63]. Interestingly, the regiments were headed by the boyar, Yakov Kudenetovich Cherkassky, an opponent of B. I. Morozov. Cherkassky was sent to Tula, away from the capital, where the struggle to exert influence on the young czar was in full swing. Envoy Alexei Nikitich Trubetskoy was not a random choice either: he was the only heir of the Trubetskoys and a nephew of the famed hero of the Smuta (the Time of Troubles), Dmitry Timofeyevich Trubetskoy, who laid claim to the Russian throne in 1613.

Such were the circumstances in July 1645 when the oath of allegiance to Alexei Mikhailovich was taken. The procedure of swearing in (kissing the cross) was practically the same in all towns; as such the process in the town of Yelets will serve as a good example [РГАДА, ф. 210, оп. 7а, д. 98, л. 95-151]. The ritual of kissing the cross occurred in the cathedral of the town where all the male population was gathered. The oath itself depended upon the rank and title of the person pronouncing it.

A special order was issued that the representatives of Moscow's aristocracy were to be sent to different towns. This served to demonstrate that succession to the throne could only be by right of inheritance. However, according to official documentation, the act of being sworn in was "the czar's great zemskoye delo (a matter for local government in rural districts in which the nobility prevailed)" [Ibid., л. 95]. The message sent to the towns, which were the first to register the oath of allegiance, stressed that the oath was not only for the ruling class. The message also emphasized that the new czar had been elected not because some people merely wanted it to be that way. Instead, the accession of the new czar was a matter for the whole population, the business of the zemstvo (government in rural districts), because in 1613, his father, the founder of the ruling dynasty, was elected by the sobor (meeting), i.e. "the whole land". This tradition continued in 1645, as the populace was again called upon with the new Zemstvo and charged to install the son of the first Romanov czar to the throne.

The official idea of the role of the "zemskoye delo" in the oath of allegiance to the czar was so powerful that G.K. Kotoshikhin, in his writings about Russia for the ruling elite of Sweden, stated that Alexei Mikhailovich was crowned by the representatives of all ranks and groups, i.e. "the whole land" [Котошихин, с. 14]. On this basis, several historians have supposed that the czar was elected at the Zemskiy sobor (a meeting of the local government in a rural district) [Андреев, с. 61]. However, evidence does not support the existence of elections within town meetings. Nevertheless, 
G. K. Kotoshikhin's work emphasizes the importance of the "zemskoye delo" as a basis for taking the oath of allegiance (by kissing the cross) to the new czar.

The oath of allegiance registry provides instructions as to how the swearing of allegiance was to take place. It states in what order the population of the town was to be led "to the cross": first the voevoda, the starosta (village elder), the streltsi (the military) and the Cossacks, and the sotniks (commander of a unit hundred), the boyar children, the land-owning esauls (Cossack rank) and Cossacks, and the streltsi, and the Cossacks, and all kinds of people in service and finally the local people, according to the lists [РГАДА, ф. 210, оп. 7а, д. 98, л. 95-96 об.]. For the oath of allegiance the town voevoda prepared the lists of all the male population of the town, and the procedure was to take place in accordance with these lists.

It often happened that the voevoda's children, those that were at least 15 years of age, were in town with him. In such cases the voevoda came to kiss the cross together with his sons. Then, if Muscovite noblemen, tradesmen, citizens of other towns happened to be in town on that day, they were also taken to swear allegiance, being included in the first (i.e. most important) list. The list of those who had taken the oath of allegiance was to be as complete as possible, which was the main aim. Indeed, those who had not taken the oath could be accused of treason.

The clerics who "held the cross" occupied a very important place in the ritual of kissing the cross. Great attention was paid to the ceremony, how the ritual was carried out. Usually, all the Fathers Superior of the local monasteries and the cathedral priests were "with a cross".

The uezd nobility, the basis of the army, performed an important role. Their names were placed in a separate list. This list was divided into groups depending on the stan (administrative and police sector of the uezd) where the nobleman resided and the tax levied upon him. The landowners who paid the biggest tax came first. This principle was connected with the czar's property. That is, the landowners owned land which belonged to the czar, so the landowners would be the first "to fulfill obligations" concerning the czar's affairs.

At the end of the cross-kissing registry there was a very detailed list of persons who were supposed to take the oath but did not appear at the ceremony. If known, the reason for their absence was always given. In most cases, it was because they were away on business (sluzhiloye part of the population - state or military officials), or trading at fairs for the posadskiye (deputies of the prince) [РГАДА, ф. 210, оп. 7а, д. 98, л. 150-151].

Thus the oath of allegiance registries reflect the character and composition of the country after Mikhail Fedorovich's death. These registries reinforce official policy in the capital, which was aimed to instate the new czar as the rightful successor to the throne. Nevertheless, the procedure of his election was understood as "zemskoye delo", i.e. a common affair. Indeed, in the $17^{\text {th }} \mathrm{c}$. the zemstvo was usually associated with elections: "zemskoye delo" included the election of starosta (village elder) in the free settlements (sloboda), tax collectors, heads of inns and customs, elders in towns and uezds. Alexei Mikhailovich became czar by right of succession and was also 
declared czar through the perceived right by election. The contradiction here is only a seeming one, because in July 1645 the throne was assumed by the legitimate son of an elected czar, and the oath to him was understood as "zemskoye delo".

The "kissing of the cross" was closely watched by the state because the political and social conditions were far from stable. For this reason, the swearing in was scheduled to take place in Moscow within one or two months. This urgency can be explained by the struggle between B. I. Morozov's group and his opponents. B. I. Morozov, new in power, sought to crown the young prince as quickly as possible and make the population take an oath of allegiance. This way, the opposition, even if it had wanted to, would not have had time to take the struggle out of the Kremlin and into the streets of Moscow, and from Moscow, into the provincial towns.

The oath of allegiance registries demonstrate that the oath of allegiance to the new czar took place without incident in the towns. The real struggle, however, took place in the capital, in the highest aristocratic circles. B. I. Morozov feared that the opposition might use popular unrest to further its own political interests, but that did not come about. The political struggle was carried on only within the walls of the Kremlin.

Although B.I. Morozov's group triumphed, it was clear already in August 1645 that consensus had not been reached in the upper echelons of power, and the struggle became more apparent. Possibly in July 1645, Cherkassky, the Romanovs and the Sheremetevs still thought that they could come to a peaceful agreement with B. I. Morozov, and if not, then they could easily cause him to fall from favour through court intrigues. That is why the kissing of the cross was performed without incident, though somewhat in a hurried fashion. By August 1645, however, B. I. Morozov had seized control, and the opposition required more serious measures, such as turning popular unrest into open rebellion.

What B. I. Morozov was afraid of in July-August 1645 happened in July 1648 [Ляпин, 2011, с. 207-217].

Акты Московского государства. СПб., 1892. Т. 2, № 246. С. 154. [Akty Moskovskogo gosudarstva. SPb., 1892. T. 2, N 246. S. 154.]

Андреев И. Л. Алексей Михайлович. М., 2006. [Andreev I. L. Aleksej Mikhajlovich. M., 2006.]

Бахрушин С. В. Политические толки в царствование Михаила Федоровича // Бахрушин С. В. Труды по источниковедению, историографии и истории России эпохи феодализма (научное наследие). М., 1987. С. 87-118. [Bakhrushin S. V. Politicheskie tolki v tsarstvovanie Mikhaila Fedorovicha // Bakhrushin S.V. Trudy po istochnikovedeniyu, istoriografii i istorii Rossii epokhi feodalizma (nauchnoe nasledie). M., 1987. S. 87-118.]

Смирнов П. П. Челобитные дворян и детей боярских всех городов в первой половине XVII в. // ЧОИДР. 1915. № 3. С. 50-60. [Smirnov P. P. Chelobitnye dvoryan i detej boyarskikh vsekh gorodov v pervoj polovine XVII v. // CHOIDR. 1915. № 3. S. 50-60.]

Ляпин Д. А. Социальный состав участников волнений в городах России в середине XVII в. // Русистика Руслана Скрынникова : сборник статей памяти профессора Р. Г. Скрынникова, в честь его 80-летия / под ред. Д. Свалка и И. О. Тюменцева. Будапешт ; Волгоград, 2011. C. 207-215. [Lyapin D. A. Sotsial'nyj sostav uchastnikov volnenij v gorodakh Rossii v seredine XVII v. // Rusistika Ruslana Skrynnikova : sbornik statej 
pamyati professora R.G. Skrynnikova, v chest' ego 80-letiya / pod red. D. Svalka i I.O. Tyumentseva. Budapesht ; Volgograd, 2011. S. 207-215.]

Ляпин Д. А. Народные волнения в России в середине XVII в. // Вопросы истории. 2010. № 4. C. 15-28. [Lyapin D. A. Narodnye volneniya v Rossii v seredine XVII v. // Voprosy istorii. 2010. N 4. S. 15-28.]

Котошихин Г. К. О России в царствие Алексея Михайловича. СПб., 1859. [Kotoshikhin G. K. O Rossii v tsarstvie Alekseya Mikhajlovicha. SPb., 1859.]

Кочелева О. Е. Лето 1645 года: смена лиц на российском престоле // Казус 1999. Индивидуальное и уникальное в истории. М., 1999. С. 155-157. [Kosheleva O. E. Leto 1645 goda: smena lits na rossijskom prestole. Kazus 1999. Individual'noe i unikal'noe v istorii. M., 1999. S. 155-157.]

РГАДА. Ф. 210 (Разрядный приказ). [RGADA. F. 210 (Razryadnyj prikaz)].

Щербакова О. История Казанского храма в Узком : очерки. М., 2000. [Scherbakova O. Istoriya Kazanskogo khrama v Uzkom : ocherki. M., 2000.]

Статья посвящена политической борьбе в высших кругах России летом 1645 г., связанной со смертью царя Михаила и коронацией его сына Алексея Михайловича. Автор показывает противоречия, сложившиеся в это время в аристократических кругах, которые нашли отражение в крестоприводных записях, использовавшихся для приведения к присяге новому государю населения городов в июле - августе 1645 г. В конце статьи делаются выводы о том, что политическая борьба в России летом 1645 г. не приняла широкий размах, поскольку противники пришедшего к власти боярина Б. И. Морозова надеялись на скорую победу или компромисс. Это нашло отражение в крестоприводных записях. Однако через несколько лет, так и не добившись успеха, оппозиция стала использовать более широкие методы борьбы, связанные с народными волнениями 1648 г.

Ключевы е слова : крестоприводные записи; присяга; царь Алексей Михайлович; Б. И. Морозов.

Denis Liapin (Денис Александрович Ляпин), dr.

Russia, Yeletsk

Yeletsk State University

denis-1@mail.ru 